\title{
Effects of Aqueous Leaf Extract of Simarouba glauca DC (Simaroubaceae) on Lipoprotein Homeostasis and Oxidative Stress Biomarkers
}

\author{
Sammydavies E. Osagie-Eweka ${ }^{1 *}$, Noghayin J. Orhue ${ }^{1}$, Eric I. Omogbai ${ }^{2}$
}

${ }^{I}$ Department of Biochemistry, Faculty of Life Sciences, University of Benin, P.M.B 1154, Benin City, Nigeria.

${ }^{2}$ Department of Pharmacology and Toxicology, Faculty of Pharmacy, University of Benin

"Corresponding Author Email: davies.osagie-eweka@uniben.edu

Phone: $\underline{\text { Tel: }}+2348059863056$

\section{ARTICLE HISTORY}

Received: $3^{\text {rd }}$ June, 2021

Accepted: $15^{\text {th }}$ September, 2021

\section{KEYWORDS \\ Simarouba glauca; Lipid Profile; Dyslipidemia; Oxidative Stress.}

Pharmacology and Toxicology of Natural Medicines ISSN: 2756-6838

Published by Phytomedicine Research Group, Department of Pharmacology \& Toxicology, Faculty of Pharmacy, University of Benin, Benin City 300001, Nigeria

\begin{abstract}
Background and Purpose: Simarouba glauca is widely reported to contain a number of biologically active compounds with potentials in the treatment of numerous diseases. The study was conducted to evaluate the sub-acute effects of the aqueous leaf extract of Simarouba glauca (AESG) on lipoproteins and oxidative stress biomarkers in male Wistar rats.

Methods: Oral administration of AESG was carried out in line with the guidelines of the Organization for Economic Co-operation and Development (OECD), No. 425 using a total of 24 male Wistar rats allotted to four groups $(n=6)$; given distilled water, 500, 1000, and $2000 \mathrm{mg} / \mathrm{kg} /$ day of AESG respectively for 30 days.

Results: In plasma, there was a significant reduction $(P<0.05)$ in HDL-cholesterol; elevated $(P<0.05)$ triglycerides $(\mathrm{TG})$ at 1000 and $2000 \mathrm{mg} / \mathrm{kg} / \mathrm{day}$; elevated $(P<0.05)$, and LDLcholesterol at 500 and $1000 \mathrm{mg} / \mathrm{kg} / \mathrm{day}$, relative to the control. While the level of liver total cholesterol (TC) reduced significantly, it increased in the heart. Catalase (CAT) activity in the liver increased significantly $(P<0.05)$ at all doses. The dose of $1000 \mathrm{mg} / \mathrm{kg} / \mathrm{day}$ significantly $(P<0.05)$ elevated kidney CAT activity. The activities of superoxide dismutase (SOD) in liver and heart reduced $(P<0.05)$ at $500 \mathrm{mg} / \mathrm{kg} / \mathrm{day}$. At all doses, the levels of reduced glutathione $(\mathrm{GSH})$ in plasma, liver and heart were comparable with the control. Although, there were no significant changes in plasma and liver glutathione peroxidase (GSH-PX) activity at all doses, animals given $500 \mathrm{mg} / \mathrm{kg}$ had reduction $(P<0.05)$ in the heart GSH-PX activity compared to the control.

Conclusion: Oral sub-acute AESG at high doses altered lipid homeostasis in plasma and heart without lipid peroxidation or oxidative stress. The extract has the potential to cause hyperlipidemia.
\end{abstract}

LICENSE: This article by Pharmacology and Toxicology of Natural Medicines is licensed and published under the Creative Commons Attribution License 4.0 which permits unrestricted use, distribution, and reproduction in any medium, provided this article is duly cited. COPYRIGHT: The Author(s) completely retain the copyright to this published article. OPEN ACCESS: The Author(s) approves that this article remains permanently online in the open access (OA) model. QA: This Article is published in line with the principles of "COPE (Committee on Publication Ethics) and PIE (Publication Integrity \& Ethics)". 


\section{INTRODUCTION}

Lipids form an integral part of the cell composition with several support to the existence and survival of cells. Lipids play important roles in the human body as hormones or hormone precursors, aiding digestibility, providing energy, storage and metabolic fuels (Chung, 2021). They also act as functional and structural components of bio-membranes, form insulation to enable nerve conduction and prevent heat loss (Chung, 2021); amongst others. High-density lipoprotein cholesterol (HDL-C), otherwise regarded as good lipoprotein cholesterol has been reported to function in the removal of cholesterol from peripheral cells and systemic circulation to the liver where it is converted to bile acids and excreted into the intestine (Wang and Briggs, 2004)., Plasma low density lipoprotein cholesterol (LDL-C) are a class of plasma lipoproteins that is regarded as bad cholesterol due to its strong pathological correlation with cardiovascular complications (Cesare et al., 2005). It has also been reported that oxidized LDL-C resulting from oxidative stress can be injurious to vascular endothelium rendering it dysfunctional (Steinberg, 1997). Epidemiological studies have also implicated elevated triglycerides (TG) and reduced HDL in cardiovascular diseases (Hokanson and Austin, 1996; Nordestgaard, 2014). Lipids form a component of plant cell membrane in varying proportions depending on taxonomical classification and varieties of plants exhibit medicinal properties. Several toxicological studies have shown that a number of medicinal plant supplements affect lipid metabolism ranging from hypolipidemia to severe dyslipidemia (Perez et al., 1999; Adebayo et al., 2006; Ogbonnia et al., 2010; PatrickIwuanyanwu et al., 2012; Zaza et al., 2016). Although herbal medicinal supplements are generally considered safe, some are known to be toxic at high doses, while others may be potentially toxic after prolonged use (Patrick-Iwuanyanwu et al., 2012).

The antioxidative effect of phytotherapeutic principles inherent in medicinal plants have been exhaustively researched and reported (Patel et al., 2011; Afagnigni et al., 2017; Akindele et al., 2018; Kale et al., 2019; Shehu and Yabagi, 2019). The pro-oxidant action of phenoxyl radicals generated from the electron-donating action of phenolic compounds has been strongly implicated in inducing oxidative stress (Sakihama et al., 2002). This suggests that medicinal herbal supplements that contain phenolics may generate phenoxyl radicals as the primary oxidizing agents (Sakihama et al., 2002) capable of initiating lipid peroxidation.

Herbal medicinal preparations have been in use for thousands of years in developing and developed countries owing to their natural origin and presumed safety (Kamboj, 2012). Several plant metabolites such as alkaloids, anthraquinone glycosides, pyrrolizidine alkaloids amongst others have been implicated in toxicity (Rowin and Lewis, 1996; Becker et al., 1996; George, 2011). Therefore, the present study evaluates the safety of evaluation of the leaf extract of Simarouba glauca with respect to lipoprotein metabolism and oxidative stress.

Simarouba glauca, commonly known as "Paradise tree" or "Laxmitaru" belongs to the family Simaroubaceae (Patil and Gaikwad, 2011). S. glauca has a long history of herbal medicine application giving its many pharmacological properties that have been documented (Patil and Gaikwad, 2011). The stem-bark and leaf of S. glauca contain triterpenes useful in treating amoebiasis, diarrhea and malaria. Chemicals present in leaf, fruit, pulp and seed of $S$. glauca have been reported to possess analgesic, antimicrobial, antiviral, astringent, emmenagogue, stomachic, tonic, vermifuge properties (Joshi and Joshi, 2002). The major active groups of phytochemicals in $S$. glauca are the quassinoids, which belong to the triterpene chemical family. Ailanthinone, glaucarubinone and holacanthone are considered as some of the main active quassinoids in genus Simarouba. Other chemicals include benzoquinone, canthin, dehydroglaucarubinone, glaucarubine, glaucarubolone, melianone, simaroubidin, simarolide, simaroubin, simarubolide, sitosterol and tirucalla (Technical Data Report for Simarouba (Simarouba amara), 2002).

\section{MATERIALS AND METHODS}

\section{Collection of $S$. glauca Leaves and Preparation of Aqueous Extract}

Leaves of $S$. glauca were collected from Cercobela Farms ${ }^{\circledR}$, Ubiaja, Esan South East Local Government Area of Edo State, Nigeria. The plant was authenticated and at the Department of Plant Biology and Biotechnology, University of Benin where a herbarium voucher specimen (N0. $\mathrm{UBH}_{\mathrm{S}} 382$ ) has been deposited. The leaves were rinsed with tap water and air-dried at room temperature at the Department of Biochemistry, University of Benin, for twenty-eight (28) days. Leaves were pulverized and sieved at the Department of Pharmacognosy, Faculty of Pharmacy, University of Benin, to obtain fine a fine powder. A quantity (500 g) of the leaf powder was soaked in $2.5 \mathrm{~L}$ of distilled water and stirred at intervals for $24 \mathrm{~h}$, and filtered. The left over material was reextracted in another portion of $2.5 \mathrm{~L}$ of distilled water and stirred at intervals for another $24 \mathrm{~h}$. Both filtrate portions were pooled and freeze-dried (Osagie-Eweka et al., 2016), The yield of extraction was $6 \% \mathrm{w} / \mathrm{w}$.

\section{Chemicals and Reagents Test Kits}

Randox $^{\circledR}$ total cholesterol kit (Pipes buffer, 4aminoantipyrine, phenol, peroxidase, cholesterol esterase 
and cholesterol oxidase), Randox ${ }^{\circledR}$ TG (Pipes buffer, 4chloro-phenol, $\mathrm{Mg}^{2+}$, 4-aminophenazone, ATP, lipase, glycerol-kinase, glycerol-3-phosphate oxidase, peroxidase), Randox ${ }^{\circledR}$ HDL-cholesterol (cholesterol oxidase, phosphotungstic acid and $\mathrm{MgCl}_{2}$ ); were all purchased from Randox Laboratory (United Kingdom). Thiobarbituric acid (TBA), glacial acetic acid, phosphate buffer, $\mathrm{H}_{2} \mathrm{SO}_{4}, \mathrm{KMNO}_{4}$, carbonate buffer, 5,5-dithio-bis(2-nitrobenzoic acid) (DTNB), potassium phosphate buffer, $\mathrm{H}_{2} \mathrm{O}_{2}$, and pyrogallol were obtained from reputable manufacturers. All reagent solutions were freshly prepared.

\section{Experimental Animals}

A total of 24 male Wistar rats weighing between 184 and $200 \mathrm{~g}$ were used for the study. The animals were housed in metabolic cages, fed with normal commercial pellets (Livestock Feeds ${ }^{\circledR}$ ) and drank water ad libitum. They were maintained under laboratory conditions of $12 \mathrm{~h}$ light/ $12 \mathrm{~h}$ dark cycle and were acclimatized for two weeks prior to commencement of studies. All experiments were conducted in accordance with the internationally accepted guidelines for laboratory animal use. The protocols were approved by the Faculty of Pharmacy, University of Benin Ethics Committee with reference number EC/FP/021/11.

\section{Oral Administration of AESG}

The study was conducted as prescribed in the OECD No. 425 test guidelines (Organisation for Economic Cooperation and Development, 2008) as described by Rout et al. (2014) and Oliveira et al. (2016). The rats were randomly allotted into four (4) groups $(n=6)$. Test animals received oral doses of 500, 1000, and $2000 \mathrm{mg} / \mathrm{kg}$ body weight respectively of AESG daily for thirty (30) days while the control group received only water ad libitum.

\section{Collection of Samples and Specimens}

On the $30^{\text {th }}$ day the rats were fasted overnight. The following day, they were anesthetized in a chloroformsaturated chamber and sacrificed. Samples of blood were withdrawn from the thoracic aorta into heparinized specimen bottles. The blood samples were centrifuged at $3,500 \mathrm{rpm}$ for $10 \mathrm{~min}$ to obtain plasma samples which were stored at $-18^{\circ} \mathrm{C}$ but were used for biochemical analyses within a few days. Kidney, liver, and heart were excised from each rat, cleared off connective tissues and homogenized in $5 \mathrm{~mL}$ normal saline using a refrigerated homogenizer (Model 153.02, California, USA). The homogenate was centrifuge at $3500 \mathrm{rpm}$ for $15 \mathrm{~min}$ to obtain a clear supernatant which was stored and used as described for plasma samples

\section{Biochemical Analyses}

Lipid profile tests which include total cholesterol (TC), high density lipoprotein cholesterol (HDL-C), triglyceride (TG) and low density lipoprotein cholesterol (LDL-C) were done using colorimetric methods and calculative method described by Roeschlaw et al. (1974), Jacobs and Van Denmark (1960), and Friedewald et al. (1972) respectively using commercial test kits (Randox ${ }^{\circledR}$ Laboratories, United Kingdom). Stress related oxidative status was evaluated by determining the levels/activities of malondialdehyde (MDA), catalase (CAT), superoxide (SOD) reduced glutathione (GSH) and glutathione peroxidase (GSH-PX) according to the methods reported by Gutteridge and Wilkins (1982), Cohen et al. (1970), Misra and Fridovich (1972), Ellman (1959) and Chance and Maehly (1955) respectively.

\section{Statistical Analysis}

Data are expressed as mean \pm SD (standard deviation). Differences between means of test groups were evaluated by one-way analysis of variance (ANOVA) followed by Tukey's multiple comparison test. Differences were considered significant at $P<0.05$. All statistical analyses were conducted using GraphPad prism ${ }^{\circledR}$, version 7.

\section{RESULTS}

\section{Effect of Oral AESG on TC, TG and Lipoproteins in Wistar Rats}

Figure 1 shows a significant $(P<0.05)$ reduction in plasma HDL-C and no significant differences in plasma TC at all doses relative to the control. The Figure also shows a significant $(P<0.05)$ increase in plasma TG at AESG doses of $1000 \mathrm{mg} / \mathrm{kg} / \mathrm{day}$ and $2000 \mathrm{mg} / \mathrm{kg} /$ day respectively compared to the control. Likewise, plasma LDL-C increased significantly $(P<0.05)$ at the doses of 500 $\mathrm{mg} / \mathrm{kg} /$ day and $1000 \mathrm{mg} / \mathrm{kg} /$ day respectively compared to the control. Figure 2 shows significant $(P<0.05)$ reduction in liver and increase in heart $\mathrm{TC}$ respectively relative to the controls. 


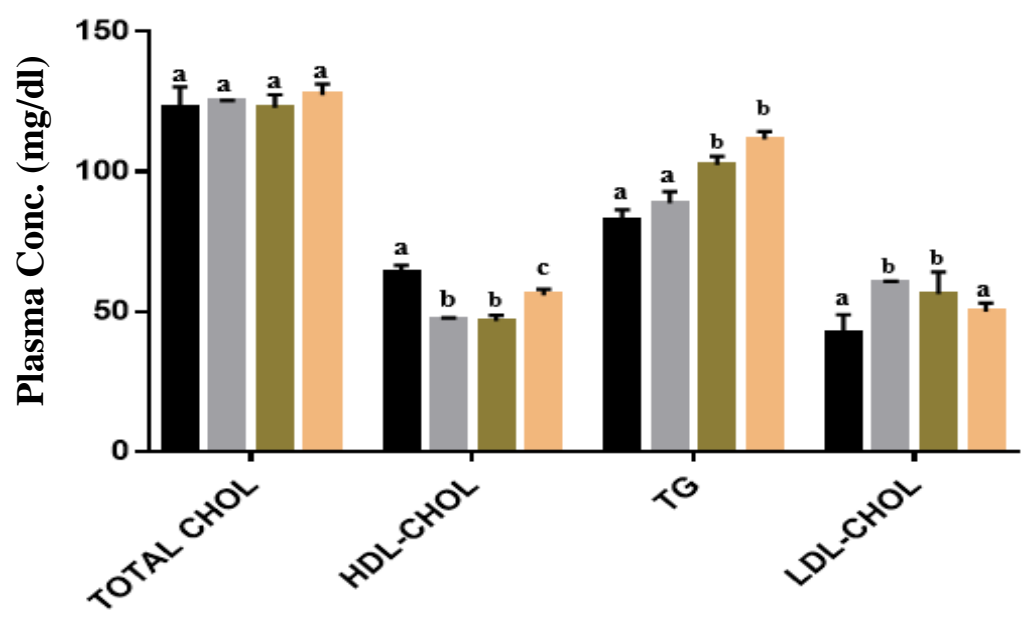

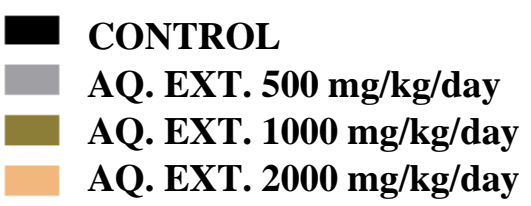

Figure 1: Effect of varying doses of aqueous leaf extract of S. glauca (AESG) on plasma TC, HDL-C, TG and LDL-C of male Wistar rats after 30 days. Data with similar lower-case alphabets are not significantly different; data with different lower-case alphabets are significantly different $(P<0.05)$. Data are presented as Mean \pm SD. $n=6$.

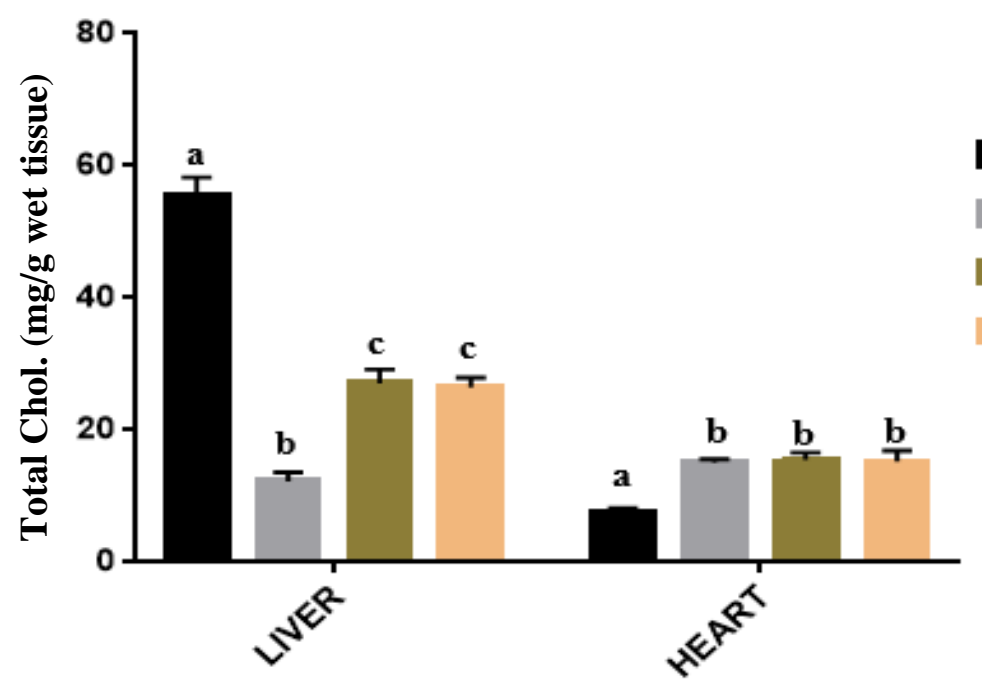

Figure 2: Effect of varying doses of aqueous leaf extract of S. glauca (AESG) on liver and heart TC of male Wistar rat after 30 days. Data with similar lower-case alphabets are not significantly different; data with different lower-case alphabets are significantly different $(P<0.05)$. Data are presented as Mean \pm SD. $\mathrm{n}=6$.

In Figure 3, there were no significant differences in liver, kidney and heart malondialdehyde (MDA) levels at all doses compared to the respective control. Figure 4 shows significant $(P<0.05)$ elevation in liver catalase (CAT) activity at all doses, significant increase in kidney CAT activity at $1000 \mathrm{mg} / \mathrm{kg} /$ day of AESG and no significant difference in heart CAT activity at all doses relative to the respective controls. Figure 5 shows significant reduction $(P<0.05)$ in liver and heart superoxide dismutase (SOD) activity at $500 \mathrm{mg} / \mathrm{kg} /$ day of AESG; and no significant difference in kidney SOD activity at all doses relative to the control.
Figures 6 and 7 show that there were no significant differences in plasma, liver and heart glutathione (GSH) levels at all doses compared to the controls. Figure 8 shows that there was no significant difference in plasma glutathione peroxidase (GSH-PX) activity at all doses relative to the control. In Figure 9, there was no significant difference in liver GSH-PX activity at all doses but it shows a significant reduction $(P<0.05)$ in heart GSH-PX activity at AESG $500 \mathrm{mg} / \mathrm{kg} /$ day compared to the controls. 


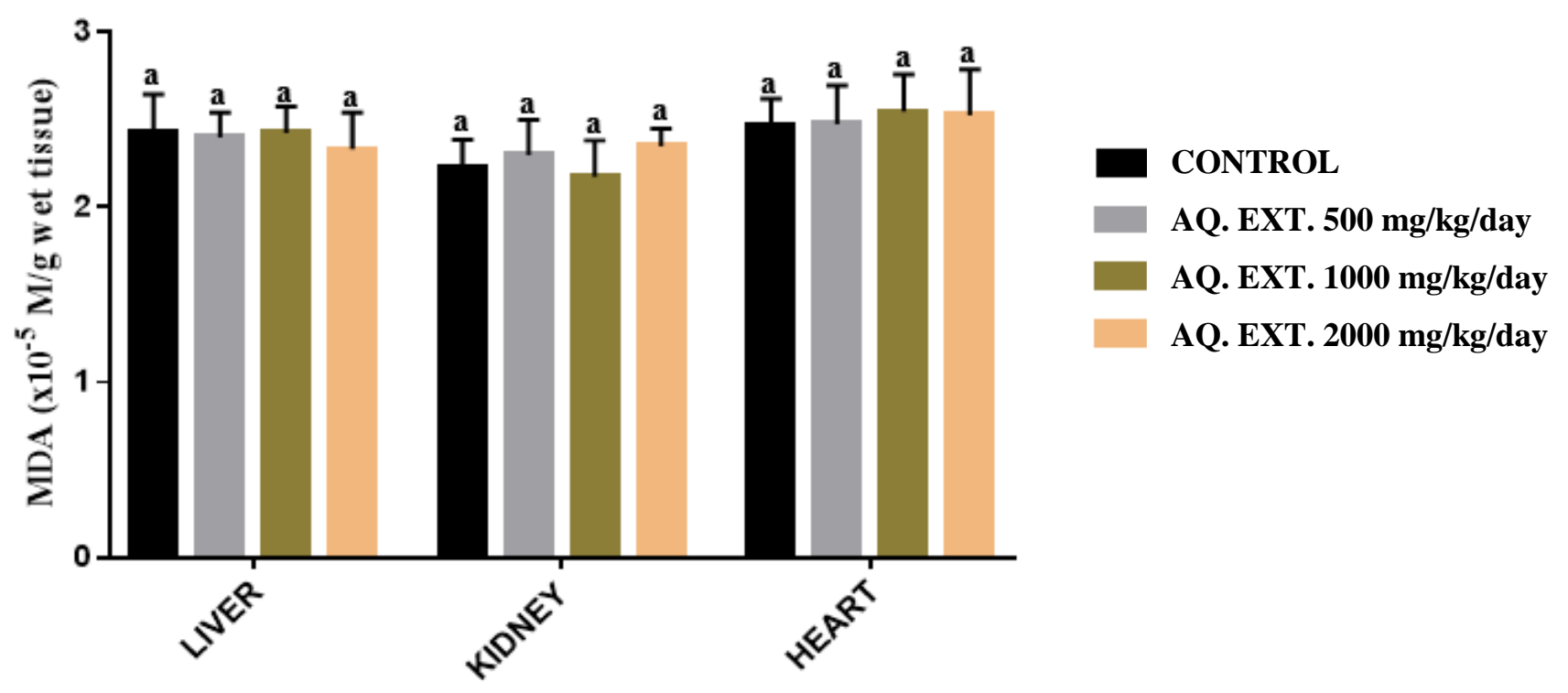

Figure 3: Effect of varying doses of AESG on liver, kidney and heart malondialdehyde (MDA) levels of male Wistar rats after 30 days. Data with similar lower-case alphabets are not significantly different. Data are presented as Mean \pm SD. $n=6$.

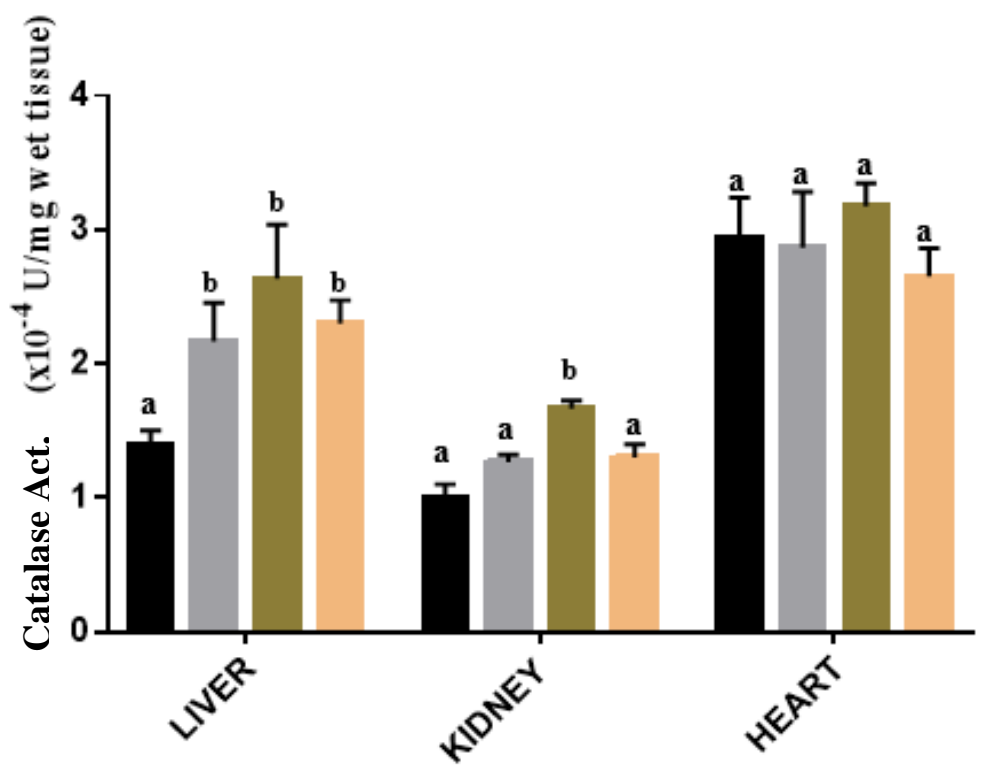

CONTROL

AQ. EXT. 500 mg/kg/day

AQ. EXT. $1000 \mathrm{mg} / \mathrm{kg} / \mathrm{day}$

AQ. EXT. $2000 \mathrm{mg} / \mathrm{kg} / \mathrm{day}$

Figure 4: Effect of varying doses of AESG on liver, kidney and heart catalase activities of male Wistar rats after 30 days. Data with similar lower-case alphabets are not significantly different; data with different lower- case alphabets are significantly different $(P<0.05)$. Data are presented as Mean \pm SD. $n=6$. 


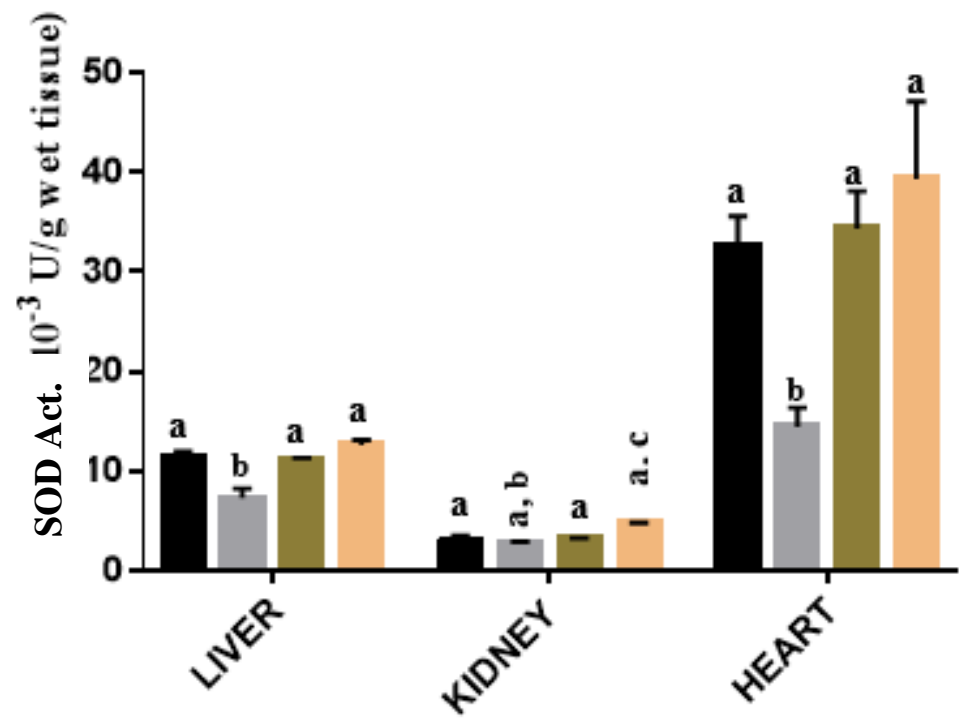

CONTROL

AQ. EXT. $500 \mathrm{mg} / \mathrm{kg} / \mathrm{day}$

AQ. EXT. $1000 \mathrm{mg} / \mathrm{kg} / \mathrm{day}$

AQ. EXT. $2000 \mathrm{mg} / \mathrm{kg} / \mathrm{day}$

Figure 5: Effect of varying doses of AESG on liver, kidney and heart SOD activities of male Wistar rats after 30 days. Results with similar lower-case alphabets are not significantly different; results with different lower- case alphabets are significantly different $(P<0.05)$. Data are presented as Mean \pm SD. $n=6$.

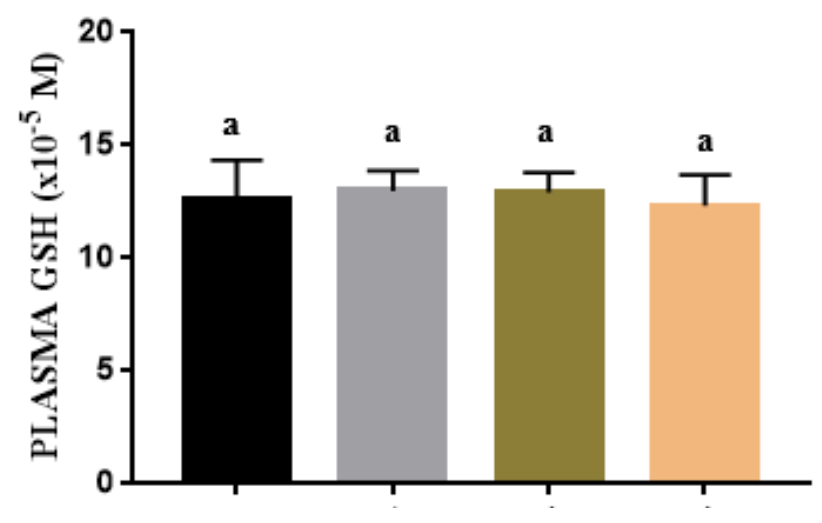

CONTROL

AQ. EXT. $500 \mathrm{mg} / \mathrm{kg} / \mathrm{day}$

AQ. EXT. $1000 \mathrm{mg} / \mathrm{kg} / \mathrm{day}$

AQ. EXT. $2000 \mathrm{mg} / \mathrm{kg} / \mathrm{day}$

Figure 6: Effect of varying doses of AESG on plasma GSH level of male Wistar rats after 30 days. Results with similar lower-case alphabets are not significantly different. Data are presented as Mean \pm SD. $n=6$. 


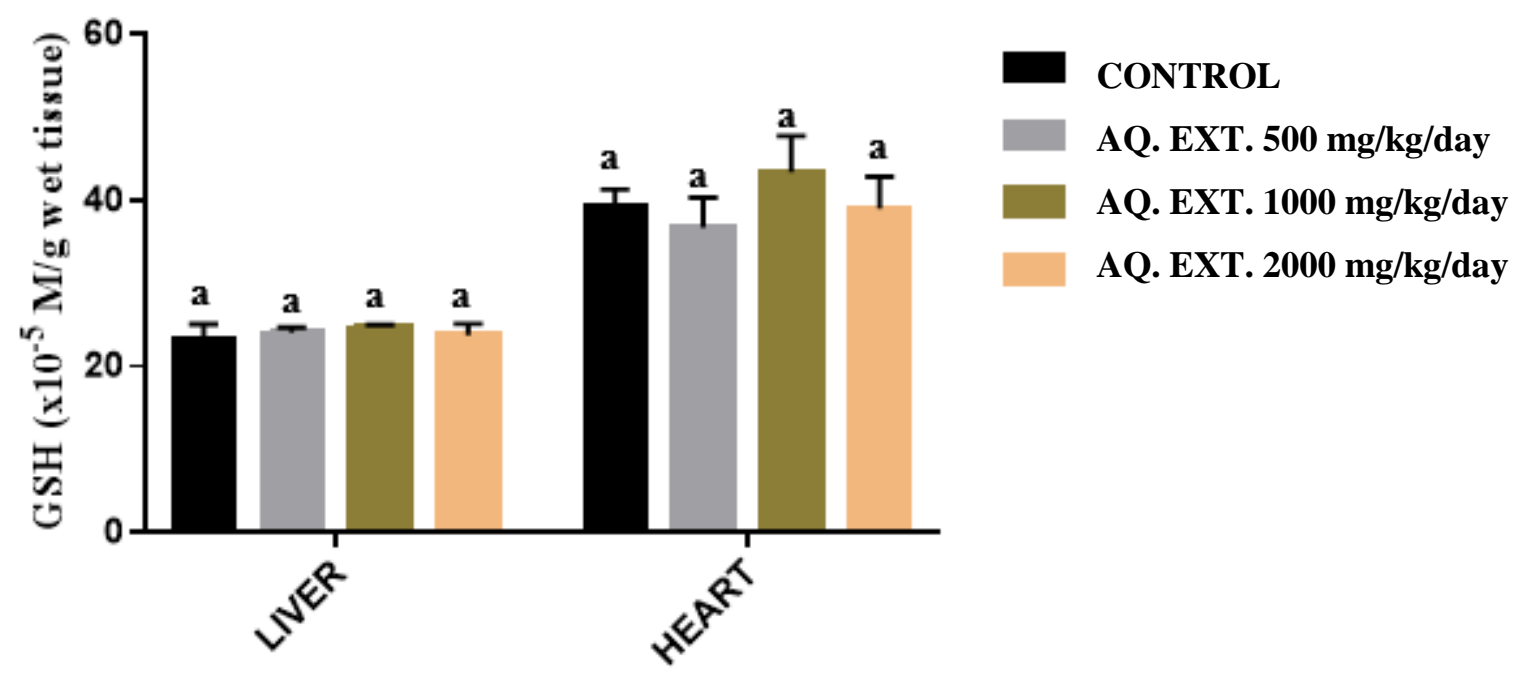

Figure 7: Effect of varying doses of AESG on liver and heart GSH levels of male Wistar rats after 30 days. Data with similar lower-case alphabets are not significantly different. Data are presented as Mean \pm SD. $n=6$.

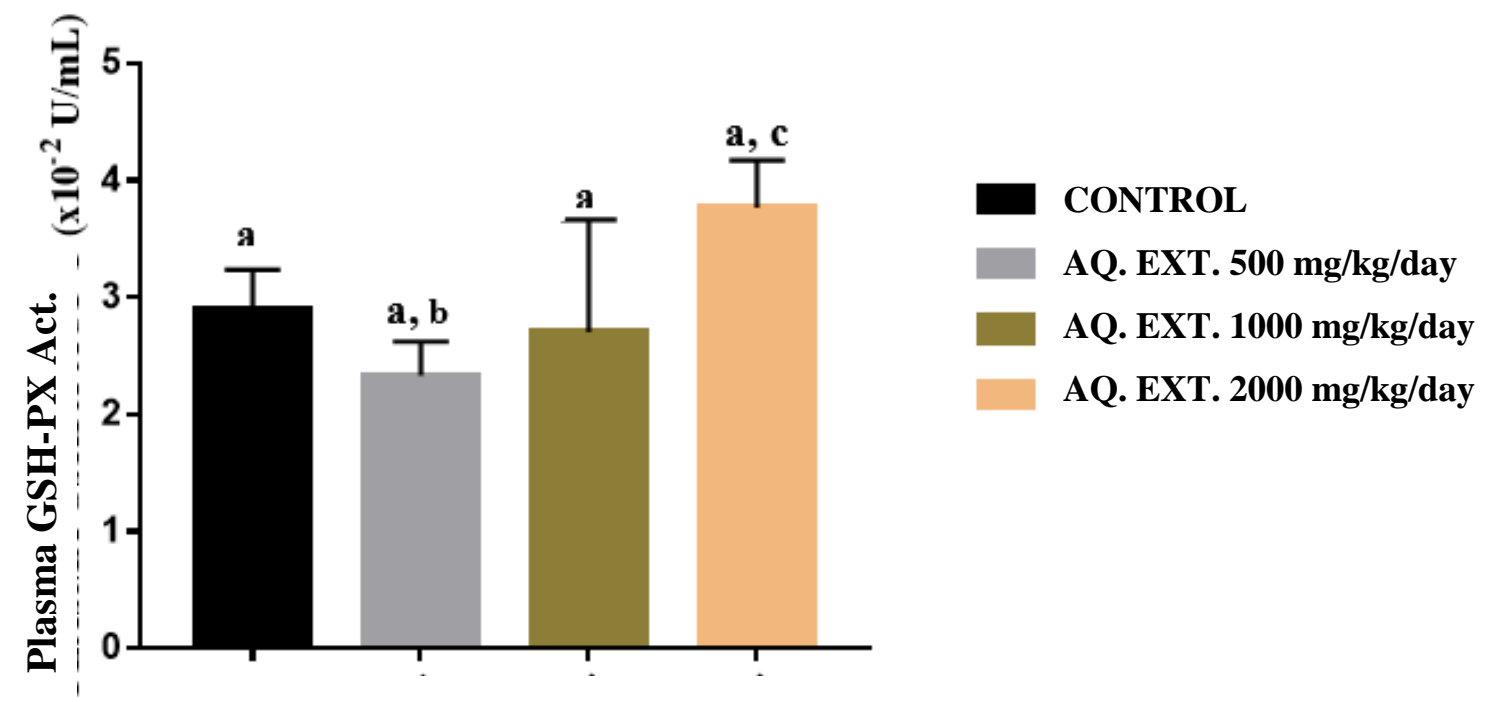

Figure 8: Effect of varying doses of AESG on plasma GSH-PX activity of male Wistar rats after 30 days. Results with similar lower-case alphabets are not significantly different; results with different lower- case alphabets are significantly different $(P<0.05)$. Data are presented as Mean \pm SD. $n=6$ 


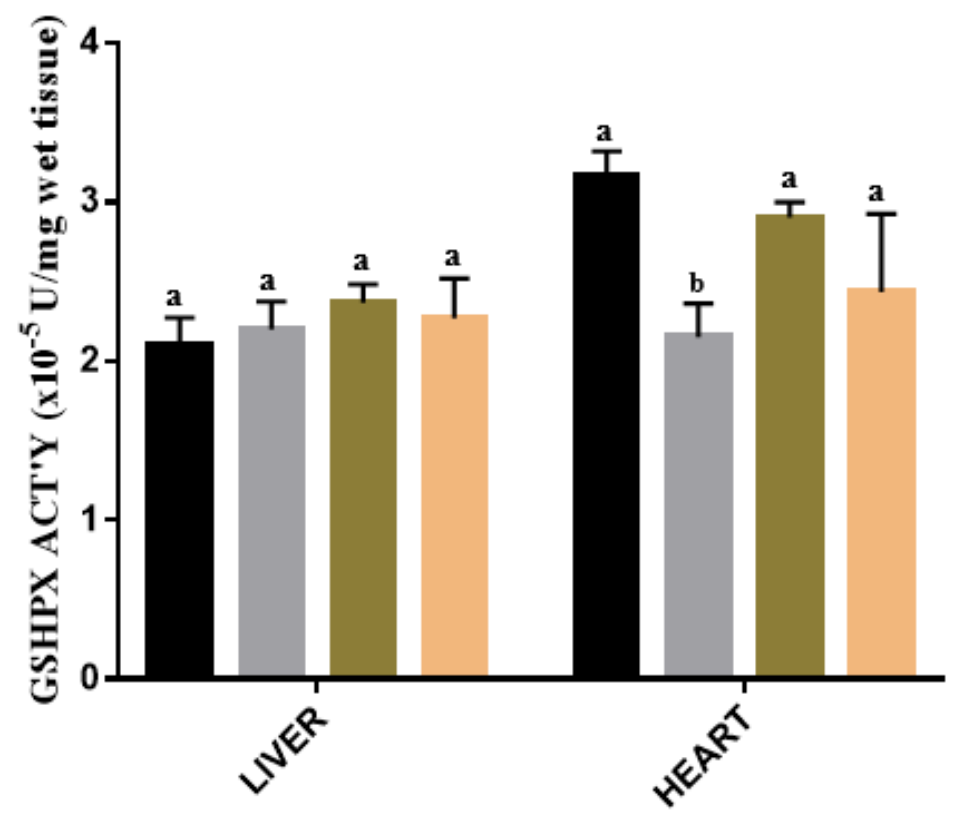

CONTROL

AQ. EXT. $500 \mathrm{mg} / \mathrm{kg} / \mathrm{day}$

AQ. EXT. $1000 \mathrm{mg} / \mathrm{kg} / \mathrm{day}$

AQ. EXT. $2000 \mathrm{mg} / \mathrm{kg} / \mathrm{day}$

Figure 9: Effect of varying doses of AESG on liver and heart GSH-PX activities of male Wistar rats after 30 days. Data with similar lowercase alphabets are not significantly different; data with different lower-case alphabets are significantly different $(P<0.05)$. Data are presented as Mean \pm SD. $n=6$.

\section{DISCUSSION}

In the present study, oral administration of AESG did not elicit obvious alteration in plasma TC although it resulted in marked increases in heart TC, plasma TG and LDLcholesterol at higher doses with corresponding reductions in liver TC and plasma HDL-cholesterol at all doses. Epidemiological and clinical studies have strongly implicated elevated triglycerides and reduced HDL in cardiovascular diseases (Hokanson and Austin, 1996; Nordestgaard, 2014) . Therefore, elevated TC and LDL-C may suggest atherosclerosis-related cardiovascular diseases such as hypertension and myocardial ischemia. High doses of AESG used in this study have demonstrated the possibility of these cardiovascular diseases. The high TC and LDL-cholesterol associated with high doses of AEGS may be due to the high free fatty acid content of Simarouba glauca plant as reported by Jena et al. (2010).

Pharmacological interventions are often driven towards developing agents capable of preventing, mitigating and (or) lowing cholesterol in the system to prevent cardiovascular diseases.

Studies on medicinal application and hypolipidemic effect of plants have been reported by Perez et al. (1999), Adebayo et al. (2006) and Ogbonnia et al. (2010). In attempts to apply these medicinal supplements for the treatment of certain diseases and conditions, there is the possibility that active compounds such as phenolics in these medicinal plants can release pro-oxidants capable of eliciting oxidative damage.
The evidence that the pro-oxidant action of phenoxyl radicals generated from the electron-donating action of phenolics compounds has been reported by Sakihama et al. (2002) and are strongly implicated in the onset of oxidative stress. In this study, AESG did not initiate responses capable of causing lipid damage or peroxidation as the MDA levels were within normal range relative to the control. However, there were elevations in selected in vivo oxidative stress enzymes, perhaps due to increase in metabolic activity associated with the metabolism of the extract.

\section{CONCLUSION}

This study has shown that although the aqueous extract of S. glauca did not induce oxidative stress, it has the potential for causing derangement in lipid levels towards hyperlipidemia. This may be a caution or contraindication in its ethnomedicinal uses.

\section{DECLARATION OF INTERESTS}

The authors declare that they have no known competing financial interests or personal relationships that could have appeared to influence the work reported in this paper.

\section{REFERENCES}

Adebayo AH, Aliyu R, Gatsing D, Garba IH (2006). The effects of ethanolic leaf extract of Commiphora africana (Buseraceae) on lipid profile in rats. International Journal of Pharmacology 2(6): 618-622. 
Afagnigni AD, Nyegue MA, Foe CFN, Ndam YN, Njayou FN, Fonkoua MC, Etoa F (2017). Antidiarrheal activity of Dissotis multiflora (Sm) Triana (Melastomataceae) leaf extract in Wistar rats and sub-acute toxicity evaluation. Journal of Evidence-Based Complementary and Alternative Medicine 4 (8): 6-15.

Akindele AJ, Oladimeji-Salami JA, Oyetola RA, Osiagwu DD (2018). Sub-chronic toxicity of the hydroethanol leaf extract of Telfairia occidentalis Hooks F. (Cucurbitaceae) in male rats. Journal of Medicine 5(4): 2-22.

Becker BN, Greene J, Evanson J, Chidsey G, Stone WJ. (1996). Ginseng-induced diuretic resistance. Journal of American Medical Association 276(8): 606-607.

Cesare R, Sirtoli CR, Fumagalli R (2005). LDLcholesterol lowering or HDL-cholesterol raising for cardiovascular prevention: A lesson from cholesterol turnover studies and others. Journal of Atherosclerosis 186: $1-11$.

Chance B, Maehly AC (1955). Enzymatic assay of peroxidase. Methods in Enzymology 11: 773-775.

Chung KW (2021). Advances in understanding of the role of lipid metabolism in aging. Cells 10: 880. https://doi.org/10.3390/ cells10040880.

Cohen G, Dembiec D, Marcus J (1970). Measurement of catalase activity in tissue extract. Journal of Analytical Biochemistry 34: 30-38.

Ellman GL (1959). Tissue sulfhydryl groups. Archive of Biochemical Biophysics 82: 70-77.

Friedewald WT, Levy RI, Fredrickson DS (1972). Estimation of concentration of low-density lipoprotein cholesterol in plasma without the use of preparative centrifuge. Journal of Clinical Chemistry 18: 499-502.

George P (2011). Concerns regarding the safety and toxicity of medicinal plants: An overview. Journal of Applied Pharmaceutical Science 1(06): 40-44.

Gutteridge JMC, Wilkins C (1982). Copper dependent hydroxyl radical damage to ascorbic acid formation of thiobarbituric acid reactive products. FEBS Letter 137: 327-340.

Hokanson J.E, Austin MA (1996). Plasma triglyceride level as a risk factor for cardiovascular diseases independent of high-density lipoprotein cholesterol level: A meta-analysis of population-based perspective study. Journal of Cardiovascular Risk 1: 312-319.
Jacobs NJ, Van Denmark PJ (1960). Colorimetric method for determination of triglycerides. Archive of Biochemistry and Biophysics 88: 250-255.

Jena PC, Raheman H, Prasanna Kumar GV, Machavaram R (2010). Biodiesel production from mixture of Mahua and Simarouba oils with high free fatty acids. Journal of Biomass and Bioenergy 34: 1108-1116.

Joshi S, Joshi S (2002). Oil tree- Laxmitaru glauca University of Agricultural Sciences, Bangalore and Indian Council of Agricultural Research, New Delhi, India. P 86.

Kale OE, Awodele O, Akindele AJ (2019). Sub-acute and Sub-chronic toxicity assessment of Acridocarpus smeathmannii (DC) Root in Wistar Rats. Journal of Toxicology Reports 6: 161-175.

Kamboj A (2012). Drug evaluation In: Analytical evaluation of herbal drugs. Chandigarh College of Pharmacy, Landran, Mohali, India Pp. 27-28.

Misra HP, Fridovich I (1972). The role of superoxide anion in the autoxidation of epinephrine and a simple assay for superoxide dismutase. Journal of Biological Chemistry 247(10): 3170-3175.

Nordestgaard BG, Varbo A (2014). Triglycerides and cardiovascular disease. Lancet 384: 625-635.

Ogbonnia SO, Mbaka GO, Anyika EN, Osegbo OM, Igbokwe NH (2010). Evaluation of acute toxicity of hydro-ethanolic extract of Chromolaena odorata (L.) King and Robinson (Fam. Asteracea) in rats. Agriculture and Biology Journal of North America 1: 859-65.

Oliveira MS, Fernandes MZLCM, Mineiro ALBB, Santos RFD, Viana GEN, Coelho JM, Ribeiro SM, Cunha APGP, Costa JF, Fernandes RM (2016). Toxicity effects of ethanol extract of Simarouba versicolor on reproductive parameters in female Wistar rats. African Journal of Biotechnology 15(8): 221-235.

Organisation for Economic Co-operation and Development (2008). Guidance document on acute oral toxicity testing OECD environment, health and safety Publications, Series on Testing and Assessment 29, No. 425. Available from: https://ntp.niehs.nih.gov/iccvam/suppdocs/feddocs/oecd/oe cd-gd129.pdf (Accessed on 23rd September, 2020).

Osagie-Eweka SDE, Orhue NEJ, Ekhaguosa DO (2016). Comparative phytochemical analyses and in-vitro antioxidant activity of aqueous and ethanol extracts of Simarouba glauca (Paradise Tree). European Journal of Medicinal Plants 13(3): 1-11.

Patel SS, Verma S, Nayak G, Singhai AK, Ganesh N (2011). Acute and sub-acute toxicity studies of Passiflora nepalensis in rats. Brazilian Journal of Pharmacognosy 21(4): 730-736. 
Patil MS, Gaikwad DK (2011). A critical review on medicinally important oil yielding plant Laxmitaru (Simarouba glauca DC). Journal of Pharmaceutical Sciences and Research 3(4): 1195-1213.

Patrick-Iwuanyanwu KC, Amadi U, Charles IA, Ayalogu EO (2012). Evaluation of acute and sub-chronic oral toxicity study of Baker Cleansers Bitters - A polyherbal drug on experimental rats. EXCLI Journal 11: 632-640.

Perez C, Canal JR, Campillo JE, Romero A, Torres MD (1999). Hypotriglyceridaemic activity of Fiscus Caarica leaves in experimental hypertriglyceridaemic rats. Journal of Phytotherapy Research 13: 188-191.

Roeschlau P, Bernt E, Gruber JW (1974). Enzymatic procedure for cholesterol determination. Journal Clinical Chemistry and Clinical Biochemistry 12: 403.

Rout PK, Rao YR, Jena KS, Sahoo D, Ali S (2014). Safety evaluation of Simarouba glauca seed fat. Journal of Food Science Technology 51(7): 1349-1355.

Rowin J, Lewis SL (1996). Spontaneous bilateral subdural hematomas associated with chronic Ginkgo Biloba ingestion. Journal of Neurology 46: 1775-1776.
Sakihama Y, Cohen MF, Grace SC, Yamasaki H (2002). Plant phenolic antioxidant and prooxidant activities: phenolics-induced oxidative damage mediated by metals in plants. Journal of Toxicology 177: 67-80.

Shehu S, Yabagi MY (2019). Investigation of acute and sub-chronic toxicity of aqueous extract of Nigerian nasal snuff in Wistar albino rats. Asian Journal of Applied Sciences 12(1): 37-44.

Steinberg D (1997). Low-density lipoprotein oxidation and its pathological significance. Journal of Biological Chemistry 272: 20963-20966.

Technical Data Report for Simarouba (Simarouba amara) (2002). Sage Press, Inc.

Wang M, Briggs MR (2004). HDL: The metabolism, function and therapeutic importance. Journal of Chemical Review 104: 119-137.

Zaza HV, Tra Bi Irié O, Gnahoué G, Kouangbé MA, Kra KAM, N'Guessan JD (2016). Oral toxicity study of X42 fraction of Terminalia ivorensis A. Chev. (Combretaceae) in Rats. International Journal of Pharmacognosy and Phytochemical Research 8(12): 1913-1919. 